JPDN ISSN 2579-6461 (Online) ISSN 2460-6324 (Print)

Jurnal Pendidikan Dasar Nusantara

Volume 6| Nomor 1| Juli 2020|

DOI: https://doi.org/10.29407/jpdn.v6i1.14286

\title{
PENGEMBANGAN MEDIA PEMBELAJARAN TAS PINTAR PADA KONSEP DASAR PERKALIAN DI SDN 1 PAPAYAN
}

\author{
Meitha Furi Dewi, Meiliana Nurfitriani, Yopa Taufik Saleh. \\ Meithafuridewi@gmail.com, Meiliana.nurfitriani@umtas.ac.id, Yopa.taufik@umtas.ac.id \\ PGSD, FKIP, Universitas Muhammadiyah Tasikmalaya
}

\begin{abstract}
Abstrak: Penelitian ini bertujuan untuk mengembangkan dan menghasilkan produk media pembelajaran tas pintar pada konsep dasar perkalian di SDN 1 Papayan. Penelitian pengembangan ini menggunakan tahapan-tahapan Research and Development (R \& D) yang mengadaptasi model 4D. Teknik analisis data yang digunakan pada penelitian ini adalah teknik analisis data kualitatif dan kuantitatif. Teknik pengumpulan data pada penelitian ini menggunakan angket dan tes awal-tes akhir. Hasil penelitian menunjukan tiga langkah yaitu Define, Design, dan Develop.Berdasarkan penilaian produk oleh ahli materi memproleh skor 4,9 pada kategori sangat baik. Penilian produk oleh ahli media memperoleh skor 5 pada kategori sangat baik. Hasil penilaian produk oleh guru memperoleh skor 5 pada kategori sangat baik. Penilaian oleh 3 orang siswa pada uji coba terbatas memperoleh skor rata-rata 5 pada kategori sangat baik. Penilaian Produk oleh 25 siswa pada uji coba lapangan memperoleh skor rata-rata 4,83 pada kategori sangat baik. Secara Keseluruhan berdasarkan hasil penilaian produk media pembelajaran tas pintar memperoleh skor 4,89 pada kategori sangat baik sehingga media pembelajaran tas pintar layak digunakan pada materi konsep dasar perkalian. Hasil pada tes awal sebelum menggunakan media pembelajaran tas pintar mendapatkan skor rata-rata 7,320 mengalami kenaikan setelah pembelajaran konsep dasar perkalian menggunakan media pembelajaran tas pintar pada tes akhir mendapatkan skor 9,120. Hasil dari penelitian ini sesuai dengan yang diharapkan yaitu siswa sudah mampu memahami konsep dasar perkalian sebagai penjumlahan yang berulang, jadi media pembelajaran tas pintar efektif untuk digunakan dalam materi konsep dasar perkalian.
\end{abstract}

Kata kunci: Media Pembelajaran, Tas Pintar, Konsep Dasar Perkalian.

\section{LEARNING MEDIA DEVELOPMENT SMART BAGS IN THE BASIC CONCEPT OF THE MESSAGE AT SDN 1 PAPAYAN}

\begin{abstract}
This study aims to develop and produce smart learning media products on the basic concept of multiplication at SDN 1 Papayan. This research development uses the Research and Development (R\&D) stages that adapt the 4D model. Data analysis techniques used in this study are qualitative and quantitative data analysis techniques. The
\end{abstract}


Kukuh, Rian, Bagus. Empat Kata Judul Dari Depan...

technique of collecting data in this study used a questionnaire and preliminary tests. The results showed three steps, namely Determining, Designing, and Developing. Based on the product evaluation by the material expert obtained a score of 4.9 in the excellent category. Assessment of the product by media experts scored 5 in the excellent category. Results The product assessment by the teacher scored 5 in the very good category. Scores by 3 students in limited trials obtained an average score of 5 in the excellent category. Product scores by 25 students in the field trials obtained an average score of 4.83 in the excellent category. Overall based on learning outcomes learning media obtained a score of 4.89 in the category of very good smart learning media worthy of being used in the basic concept material multiplication. Results on the initial test before using learning media get an average score of 7.320 increased after learning the basic concepts of multiplication using smart bag learning media on the final test getting a score of 9.120. The results of this study are in accordance with the expectations that students have been able to understand the basic concepts of multiplication as a repetitive addition, so that the smart bag learning media is effective for use in the basic concepts of multiplication.

Keywords: Learning Media, Smart Bag, Basic Concepts of Multiplication.

\section{PENDAHULUAN}

Matematika merupakan ilmu pengetahuan yang pada hakikatnya sudah ada di lingkungan sekitar manusia dan diberikan kepada setiap jenjang pendidikan mulai dari tingkat sekolah dasar hingga perguruan tinggi. Matematika menduduki peranan yang penting dalam dunia pendidikan karena Matematika adalah salah satu mata pelajaran wajib yang diajarkan pada lembaga pendidikan formal sejak pendidikan dasar. Hal ini sesuai dengan Undang-Undang Republik Indonesia nomor 20 tahun 2003 pasal 37 tentang Sistem Pendidikan Nasional yang menyatakan bahwa salah satu mata pelajaran yang wajib diberikan pada jenjang pendidikan dan menengah adalah pelajaran Matematika. Matematika perlu diberikan kepada siswa disemua jenjang pendidikan untuk membantu ketajaman berpikir secara logis dan melatih cara berpikir dalam menarik kesimpulan.

Menurut Walker dalam Sundaya (2014: 5) "Matematika merupakan studi tentang struktur-struktur abstrak dengan berbagai hubungannya" keabstrakan ini yang menjadi kendala guru dan peserta didik dalam mempelajari Matematika, konsep-konsep Matematika dapat dipahami dengan mudah apabila bersifat konkret dan nyata. Sejalan dengan teori Bruner dalam Zubaidah (2016: 105) berpendapat bahwa "belajar Matematika adalah belajar tentang konsep-konsep dan struktur, pemahaman atas suatu 
Kukuh, Rian, Bagus. Empat Kata Judul Dari Depan...

konsep beserta strukturnya menjadikan materi itu lebih mudah diingat dan dapat dipahami secara kompherensif".

Berdasarkan kutipan yang telah dijabarkan, dapat disimpulkan bahwa pembelajaran Matematika khususnya untuk Sekolah Dasar (SD) harus ditekankan pada pemahaman konsep yang baik dan benar sehingga siswa dapat mengetahui konsep dan menempatkan konsep untuk memecahkan masalah matematika. Salah satu operasi hitung yang perlu dipahami konsep dasarnya adalah perkalian. Konsep dasar perkalian seharusnya menjadi bagian penting yang diperhatikan oleh guru saat mengajar di dalam kelas, namun pada kenyataannya banyak guru yang masih mengabaikan hal tersebut.

Seperti hasil wawancara dengan guru kelas II di SDN 1 Papayan pada tanggal 2 Desember 2019 terdapat beberapa hambatan dalam pembelajaran materi konsep dasar perkalian. Hambatan tersebut yaitu ketika guru mengajarkan konsep dasar perkalian siswa kurang antusias dalam mengikuti pembelajaran, dikarenakan pembelajaran yang monoton, respon siswa kurang aktif, pembelajaran belum sesuai yang diharapkan dengan guru karena terkendala oleh dana yang tidak banyak disediakan kepala sekolah untuk mengadakan alat pendukung kegiatan mengajar, selama ini guru hanya menggunakan metode ceramah pada pembelajarannya yang nantinya peserta didik hanya diminta untuk menghafal perkalian 1-10 secara mandiri, sedangkan tidak semua peserta didik memiliki kemampuan menghafal dengan baik, sehingga dapat menghambat terhadap pemahaman konsep dasar perkalian. Hal ini dibuktikan dengan nilai hasil ulangan siswa pada materi perkalian rata-rata keseluruhan siswa dari 26 siswa hanya mencapai 59,23. Dari 26 siswa hanya $11(42,31 \%)$ siswa yang mencapai kriteria ketuntasan minimal dan 15 (57,69\%) siswa yang tidak menacapai kriteria ketuntasan minimal. Permasalahan tersebut apabila tidak secepatnya teratasi akan berdampak pada prestasi belajar siswa dan menghambat pada materi pembelajaran selanjutnya seperti pembagian, luas bangun datar, keliling bangun datar, volume bangun ruang dan sebagainya. Sebelum mempelajari materi pembagian, luas bangun datar, keliling bangun datar, volume bangun ruang dan sebagainya, maka siswa harus memahami konsep dasar perkalian terlebih dahulu.

Menurut Haeruman (2012: 2) "setiap konsep abstrak yang baru dipahami siswa perlu segera diberi penguatan, agar lebih bertahan lama dalam memori atau ingatan siswa sehingga akan melekat pola pikir dan pola tindakannya". Maka diperlukan adanya pembelajaran melalui perbuatan dan pengertian, tidak hanya sekedar hafalan atau 
Kukuh, Rian, Bagus. Empat Kata Judul Dari Depan...

mengingat fakta saja, karena hal ini akan mudah dilupakan siswa. Selain itu diperlukan pengulangan agar materi yang dipelajari semakin diingat oleh siswa. Dengan pengulangan daya-daya tersebut akan berkembang.

Pada dasarnya materi akan mudah dipahami dan diingat jika penyampaian konsep dasar perkalian dikaitkan dengan kehidupan sehari-hari dan saat proses pembelajaran menggunakan alat bantu seperti, alat peraga, media, atau benda-benda konkret yang dapat mempermudah pemahaman tentang konsep yang diberikan. Hal ini sejalan dengan teori Bruner dalam Zubaidah (2016: 109) "dalam proses pembelajaran siswa sebaiknya diberikan kesempatan untuk memanipulasi benda-benda (alat peraga)”. Dengan menggunakan alat peraga tersebut siswa dapat melihat langsung bagaimana keteraturan serta pola yang terdapat dalam benda yang sedang diperhatikannya.

Berdasarkan permasalahan di atas, maka penulis tertarik untuk mengembangkan media pembelajaran yang menarik bagi siswa, dapat membuat siswa menjadi lebih aktif, menyenangkan dan mudah diingat maupun dipahami dalam pembelajaran yaitu media pembelajaran tas pintar. Media pembelajaran tas pintar merupakan media pembelajaran yang dapat digunakan untuk membantu guru dalam mengajarkan konsep dasar perkalian pada mata pelajaran matematika. Media tas pintar memiliki tujuan mempermudah siswa dalam membentuk pemahaman pada konsep dasar perkalian. Media pembelajaran ini disebut sebagai media pembelajaran tas pintar karena pada media pembelajaran ini terdapat kayu yang berbentuk tas yang diberi angka 1-10 dengan warna yang menarik, kartu angka untuk perkalian, selain itu terdapat pula stik es krim yang berwarna. Media pembelajaran tas pintar dapat membantu siswa dalam pemahaman konsep dasar perkalian yang abstrak melalui benda konkret, dan melibatkan peserta didik langsung dalam pembelajaran sehingga dapat menghilangkan kebosanan bagi siswa ketika pembelajaran berlangsung.

Pada penelitian ini peneliti akan mengembangkan media pembelajaran tas pintar. Oleh karena itu, peneliti memfokuskan pada pengembangan media pembelajaran tas pintar pada konsep dasar perkalian di SDN 1 Papayan.

\section{METODE}

Jenis penelitian ini adalah penelitian dan pengembangan atau yang disebut juga dengan istilah R \& D (Research \& Development). Menurut Sukmadinata (2010: 164) Penelitian 
Kukuh, Rian, Bagus. Empat Kata Judul Dari Depan...

dan pengembangan $(\mathrm{R} \& \mathrm{D})$ adalah suatu proses atau langkah-langkah untuk mengembangkan suatu produk baru atau menyempurnakan produk yang telah ada, yang dapat dipertanggungjawabkan. Produk tersebut tidak selalu berbentuk benda atau perangkat keras (hardware), seperti buku, modul, alat bantu pembelajaran dikelas atau laboratorium, tetapi bisa juga perangkat lunak (software), seperti program komputer untuk pengolahan data, pembelajaran dikelas, perpustakaan, atau laboratorium, ataupun model-model pendidikan, pembelajaran, pelatihan, bimbingan, evaluasi, manajemen, dan lain-lain.

Pada metode penelitian dan pengembangan terdapat beberapa jenis model. Model yang digunakan adalah pengembangan model 4-D merupakan model pengembangan perangkat pembelajaran. Model ini dikembangakan oleh Semmel dalam Trianto (2010:189) model pengembangan 4D terdiri atas 4 tahap utama yaitu: Define (pendefinisian), design (perancangan), Develop (pengembangan) dan Disseminate (penyebaran).

Penerapan media pembelajaran tas pintar ini menggunakan $R$ \& $D$ tipe 4D pengembangan pada penelitian ini sampai tahap uji coba produk yaitu uji validasi dan revisi produk. Pada penelitian ini tidak sampai tahap uji pemakaian secara luas, revisi produk akhir dan produksi masal (Disseminate).

Teknik analisis data yang digunakan pada penelitian ini adalah teknik analisis data kuantitatif dan analisis data kualitatif. Data berupa komentar, saran para ahli, guru, dan siswa selama proses uji coba dianalisis secara deskriptif kualitatif dan disimpulkan sebagai masukan untuk memperbaiki atau merevisi produk yang telah dikembangkan. Sementara data yang berupa skor tanggapan ahli media, ahli materi, guru dan siswa yang diperoleh melalui angket dianalisis secara deskriptif kuantitatif. Selain skor dari tanggapan para ahli, guru, dan siswa yang terdapat pada angket, data hasil tes awal dan tes akhir pun dianalisis secara deskriptif kuantitatif.

Untuk mengubah data dari hasil penilaian para ahli (media dan materi), guru dan siswa yang terdapat pada angket, maka data diubah menjadi data interval. Konversi data kualitatif ke data kuantitatif yaitu menggunakan skala lima.

Tabel 1.

Konversi Data Kualitatif ke Kuantitatif

(Sumber: Widoyoko (2012: 106-112)

\begin{tabular}{|c|c|}
\hline Interval Skor & Kategori \\
\hline $4,2-5,0$ & Sangat Baik \\
\hline
\end{tabular}


Kukuh, Rian, Bagus. Empat Kata Judul Dari Depan...

\begin{tabular}{|c|c|}
\hline $3-4-4,2$ & Baik \\
\hline $2,6-3,4$ & Cukup \\
\hline $1,8-2,6$ & Tidak Baik \\
\hline $1,0-1,8$ & Sangat Kurang Baik \\
\hline
\end{tabular}

Untuk menghitung skor rata-rata dalam memberikan penilaian terhadap produk yang telah dikembangkan digunakan rumus:

\section{$\frac{\sum \text { jawaban validator }}{\sum \text { butir instrumen }}$}

Pada penelitian ini ditetapkan nilai kelayakan produk minimal dengan kategori "cukup" berdasarkan hasil penilaian dari ahli media, ahli materi, dan guru. Jika hasil penilaian akhir keseluruhan dari setiap aspek media dan aspek materi dengan nilai minimal "cukup" oleh para ahli dan guru, maka produk hasil pengembangan tersebut sudah dianggap layak digunakan sebagai media pembelajaran.

Untuk mengetahui kemampuan siswa dalam memahami materi konsep dasar perkalian dengan menggunakan media pembelajaran tas pintar di SDN 1 Papayan. dilakukan dengan uji lapangan yaitu tes awal dan tes akhir. Instrumen penilaian untuk uji lapangan adalah sebagai berikut:

Tabel 2.

Instrumen Penilaian Tes Awal dan Tes Akhir

\begin{tabular}{|c|c|}
\hline Nomor soal & Bobot soal \\
\hline $1-10$ & 10 \\
\hline Jumlah skor maksimal & 100 \\
\hline
\end{tabular}

Keterangan: Jika benar semua mendapatkan nilai 100, jika salah mendapatkan skor 0 .

Penentuan Nilai: $\mathrm{N}=\frac{\text { Skor } \text { Perolehan }}{\text { Jumlah } \text { siswa }} \times 100$

\section{HASIL}

Hasil akhir penelitian ini adalah menghasilkan produk berupa media tas pintar yang valid dan evektif dalam meningkatkan hasil belajar konsep dasar perkalian di SDN 1 Papayan. Pengembangan media tas pintar ini dilakukan melalui 3 tahap. Pertama, tahap pendefinisian (define) Proses pengembangan media ini diawali dengan pengambilan data dan informasi dilaksanakan di SDN 1 Papayan berupa wawancara untuk menetapkan syarat-syarat yang dibutuhkan dalam pembelajaran konsep dasar perkalian. Pada tahap pertama analisis awal ini peneliti melakukan wawancara dengan guru kelas II SDN 1 Papayan yaitu Ai Titik Sri Pujawati, S.Pd mengenai permasalahan dalam pembelajaran matematika pada materi konsep dasar perkalian. Hasil wawancara 
Kukuh, Rian, Bagus. Empat Kata Judul Dari Depan... dengan guru kelas II SDN 1 Papayan dalam pembelajaran matematika terdapat beberapa siswa yang mengalami hambatan dan kesulitan terutama pada materi konsep dasar perkalian, tujuan dari pembelajaran materi tersebut yaitu siswa mampu memahami konsep dasar perkalian sebagai penjumlahan yang berulang, metode yang digunakan dalam pembelajaran konsep dasar perkalian yaitu ceramah dan anak disuruh menghapalkan perkalian, dalam pembelajaran matematika materi konsep dasar perkalian tidak menggunakan media pembelajaran karena kurangnya biaya yang tersedia untuk membuat media, Respon siswa saat pembelajaran kurang aktif dan kurang antusias karena pembelajaran yang kurang menarik, Nilai rata-rata siswa 59,23 masih banyak yang kurang dari KKM. Tahap kedua analisis peserta didik analisis peserta didik dilakukan untuk mengetahui karakter peserta didik. Pada dasarnya karakteristik siswa kelas rendah kehidupannya adalah bermain, bermain bagi anak usia ini (6-8 tahun) sangatlah dibutuhkan karena pada masa ini siswa mudah jenuh dan bosan, kemudian karakteristik siswa pada usia ini lebih membutuhkan hal-hal yang bersifat konkret dari pada yang abstrak. Berdasarkan hasil wawancara dalam pembelajaran matematika pada materi konsep dasar perkalian guru tidak menggunakan media pembelajaran sehingga respon siswa pasif, sebagian siswa kurang aktif dan tidak antusias saat pembelajaran berlangsung kemungkinan karena pembelajaran yang dilakukan guru kurang menarik. Dari penjabaran tersebut, dapat dikatakan bahwa minat belajar siswa khususnya pada mata pelajaran matematika materi konsep dasar perkalian masih rendah. Pemahaman siswa pada mata pelajaran matematika materi konsep dasar perkalian masih rendah, hal tersebut dapat dilihat dari nilai hasil ulangan harian siswa yang rata-rata masih dibawa Kriteria Ketuntasan Minimal (KKM). Maka dikembangkan media pembelajaran tas pintar. Media pembelajaran ini diharapkan mampu merangsang siswa untuk belajar dan pemahaman terhadap materi konsep dasar perkalian. Tahap ketiga analisis tugas pada tahap ini peneliti telah merinci tugas isi materi ajar secara garis besar dari Kompetensi Inti (KI) dan Kompetensi Dasar (KD) yang diambil dari silabus yang digunakan di SDN 1 Papayan, terkait dengan materi yang akan dikembangkan oleh peneliti yaitu konsep dasar perkalian untuk siswa kelas II SD. Analisis konsep pada tahap ini peneliti merinci konsep yang ditujukan untuk menjabarkan indikator dan materi yang akan diajarkan, Penetapan indikator yang dilakukan oleh peneliti disesuaikan dari analisis tugas yang telah dilakukan yaitu dari Kompetensi Inti (KI) dan Kompetensi Dasar (KD), Materi yang 
Kukuh, Rian, Bagus. Empat Kata Judul Dari Depan...

digunakan oleh peneliti pada pengembangan media pembelajaran ini yaitu konsep dasar perkalian, materi yang diajarkan meliputi perkalian sebagai penjumlahan yang berulang, dan perkalian dalam kehidupan sehari-hari. Perumusan tujuan didasarkan pada KI, KD, dan indikator yang telah ditetapkan dan tercantum dalam kurikulum K13 tentang materi konsep dasar perkalian.

Kedua, tahap perencanaan (design) tahap pertama pemilihan media pada pemilihan media dilakukan untuk mengidentifikasi media dalam pembelajaran yang relevan dengan karakteristik materi. Media dipilih untuk menyesuaikan dengan analisis konsep dan analisis tugas, karakteristik target pengguna. Hal ini berguna untuk membantu peserta didik dalam pencapaian kompetensi inti dan kompetensi dasar yang diharapkan. Berdasarkan uraian diatas terdapat permasalahan dan hambatan pada saat pembelajaran matematika materi konsep dasar perkalian maka pada penelitian ini, peneliti akan mengembangkan media pembelajaran tas pintar untuk materi konsep dasar perkalian yang diharapkan sesuai dengan karakteristik pengguna, analisis konsep, dan analisis tugas yang telah di rinci oleh peneliti. Tahap kedua pemilihan format langkah-langkah penyusunan media pembelajaran tas pintar ini, diantaranya adalah menyesuaikan dengan kompetensi inti dan kompetensi dasar serta silabus berdasarkan k13. Pada penyusunan media ini pemilihan format yang digunakan pada penelitian ini yaitu Pendekatan Scientific merupakan proses pembelajaran yang dirancang agar siswa dapat lebih aktif dalam pembelajaran, tujuannya adalah mencapai tujuan pembelajaran secara efektif. Dengan menggunakan pendekatan ini diharapkan siswa dapat belajar dengan efektif dan bagi siswa yang malas belajar akan merasa cocok karena mereka merasa cara gurunya mengajar dapat membuatnya lebih cepat paham dan mudah. Strategi cooperative learning merupakan strategi pengajaran dengan cara kerja sama kelompok dan interaksi antar siswa. Teknik example non example merupakan strategi pembelajran yang menggunakan media bergambar yang mendorong siswa untuk belajar berpikir kritis. Dengan menggunakan media siswa akan lebih tertarik untuk mengikuti pembelajaran. Berdasarkan uraian tersebut maka peneliti akan mengembangkan media pembelajaran yang sesuai dengan pendekatan, strategi, dan teknik yang akan digunakan saat pembelajaran berlangsung yaitu dengan menggunakan media pembelajaran tas pintar pada konsep dasar perkalian. Tahap ketiga penyusunan instrumen pada enyusunan instrumen penelitian yang disusun terdiri dari perangkat pembelajaran dan instrumen 
Kukuh, Rian, Bagus. Empat Kata Judul Dari Depan... pengambilan data. Perangkat pembelajaran yaitu RPP, silabus. Sedangkan instrumen pengambilan data yaitu instrumen validasi produk berupa angket yang digunakan untuk mengetahui kelayakan media pembelajaran tas pintar untuk ahli materi, ahli media, guru, dan siswa. Soal tes pemahaman konsep yaitu berupa soal tes awal dan tes akhir. Tahap keempat rancangan awal pada rancangan awal dilakukan untuk membuat rancangan perangkat pembelajaran yang harus dikerjakan sebelum uji coba dilaksanakan. Maka desain dari media pembelajaran tas pintar yang akan dilaksanakan di SDN I Papayan yaitu sebagai berikut:

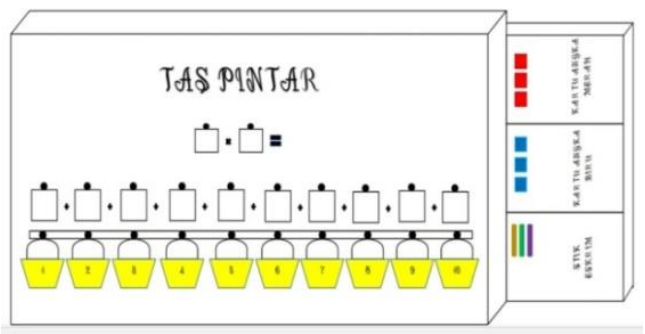

\section{Gambar 1. Desain Media Pembelajaran Tas Pintar}

Ketiga, tahap pengembangan (Develop) kegiatan yang dilakukan dalam tahap pengembangan ini adalah penilaian terhadap produk pengembangan oleh ahli materi, ahli media, guru dan siswa. Selanjutnya melakukan evaluasi terhadap produk yang telah dikembangkan. Media pembelajaran ini dikatakan baik apabila telah melalui beberapa tahap penilaian. Penilaian dilakukan oleh ahli materi, ahli media, guru. Penilaian ini adalah untuk mengetahui kualitas produk sebelum digunakan dan dinilai siswa. Penilaian yang dilakukan oleh para ahli menggunakan instrumen berupa angket. Komentar dan saran yang diberikan akan digunakan sebagai bahan pertimbangan untuk perbaikan media pembelajaran. Berikut ini adalah data hasil penilaian para ahli, guru dan siswa:

\section{Penilaian Produk dan Revisi Produk dari Ahli Media}

Penilaian media dalam media pembelajaran tas pintar ini dilakukan oleh ahli media yaitu Bapak Moh. Fahmi Nugraha, M.Pd selaku dosen yang berkompeten dalam pengembangan media pembelajaran. Penilaian media oleh ahli media ditinjau dari aspek tampilan. Hasil penilaian media pembelajaran tas pintar dapat dilihat pada tabel 3. 
Kukuh, Rian, Bagus. Empat Kata Judul Dari Depan...

Tabel 3.

Hasil Penilaian oleh Ahli Media

\begin{tabular}{|l|l|l|l|l|l|}
\hline No & Tahap & Butir & $\begin{array}{c}\text { Skor } \\
\text { Peroleha } \\
\text { n }\end{array}$ & $\begin{array}{c}\text { Rata- } \\
\text { rata } \\
\text { Skor }\end{array}$ & Kategori \\
\hline 1. & $\begin{array}{l}\text { Sebelum } \\
\text { Revisi }\end{array}$ & 10 & 36 & 3,6 & Baik \\
\hline 2. & $\begin{array}{l}\text { Sesudah } \\
\text { Revisi }\end{array}$ & 10 & 50 & 5 & $\begin{array}{l}\text { Sangat } \\
\text { Baik }\end{array}$ \\
\hline
\end{tabular}

Berdasarkan tabel 11, dapat disimpulkan bahwa media dalam penelitian ini sebelum revisi mendapatkan skor rata-rata 3,6 masuk dalam kategori "Baik" atau layak digunakan dengan revisi saran dari ahli media, selanjutnya setelah memperoleh validasi ahli media, peneliti merevisi media berdasarkan saran dari ahli media. Lalu tahap validasi media sesudah revisi mendapatkan skor rata-rata 5 masuk kedalam kategori "Sangat Baik" sehingga produk ini layak untuk di uji coba dilapangan. Revisi Produk dari Ahli Media dalam lembar angket, saran dari ahli media sebelum digunakan perlu ada beberapa perbaikan. Perbaikan yang disarankan ahli media adalah sebagai berikut: Diberi nama pada papan atau diberi judul media tersebut, gunakan gambar yang menarik di media. pakai gantungan supaya mudah disimpan. Setelah memperoleh saran dari ahli media, peneliti melakukan perbaikan atau merevisi sesuai dengan saran tersebut yaitu memberi nama atau judul pada media, lalu diberi gambar kartun dan bunga agar lebih menarik perhatian, dan dipasang gantungan menggunakan tali agar lebih praktis dan mudah disimpan. Tampilan sebelum direvisi dapat dilihat pada gambar 2 dan tampilan sesudah revisi dapat dilihat pada gambar 3 .

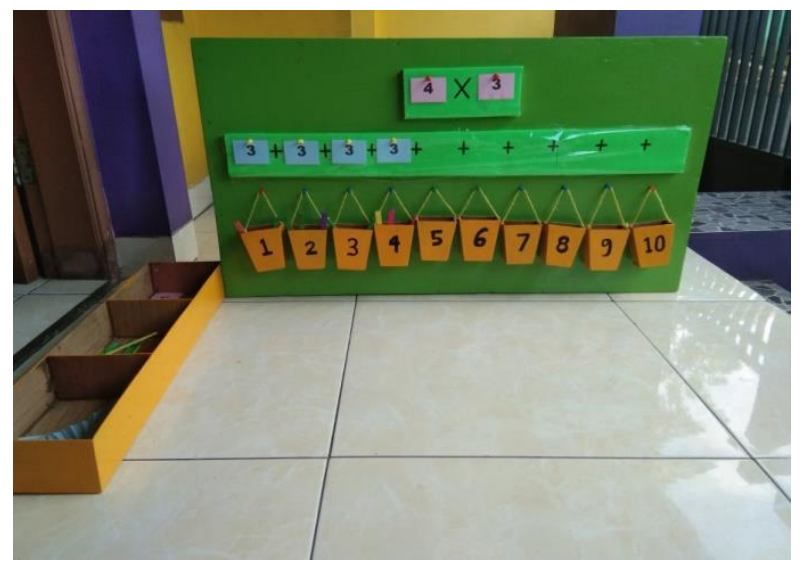

Gambar 2. Tampilan Sebelum di Revisi 
Kukuh, Rian, Bagus. Empat Kata Judul Dari Depan...

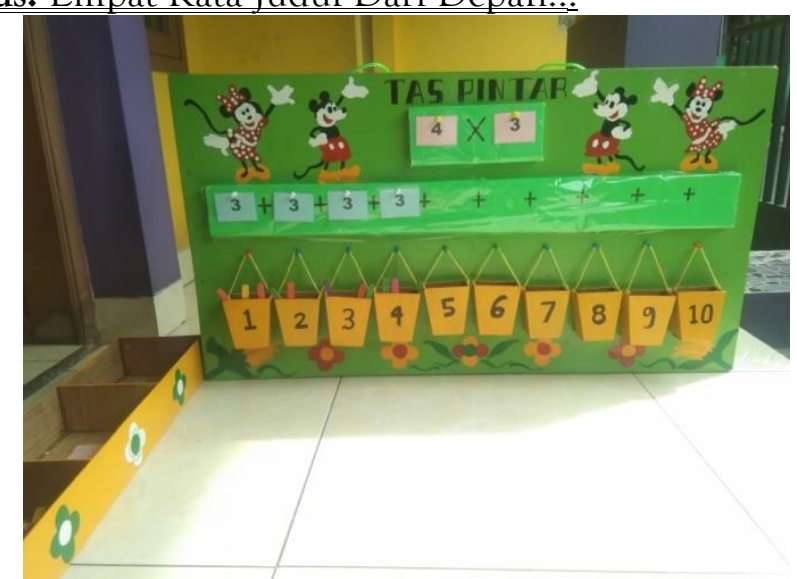

Gambar 3. Tampilan Sesudah di Revisi

\section{Penilaian Produk dan Revisi Produk dari Ahli Materi}

Penilaian materi dalam media dilakukan oleh ahli materi yaitu Ibu Milah Nurkamilah, M.Pd selaku dosen yang berkompeten sesuai materi yang disajikan yaitu tentang konsep dasar perkalian. Penilaian yang dilakukan ditinjau dari aspek materi. Hasil penilaian media pembelajaran tas pintar dapat dilihat pada tabel 4 .

Tabel 4. Hasil Penilaian Oleh Ahli Materi

\begin{tabular}{|l|l|l|l|l|l|}
\hline No & \multicolumn{1}{|c|}{ Tahap } & Butir & $\begin{array}{c}\text { Skor } \\
\text { Perolehan }\end{array}$ & $\begin{array}{c}\text { Rata- } \\
\text { rata } \\
\text { Skor }\end{array}$ & Kategori \\
\hline 1. & $\begin{array}{l}\text { Sebelum } \\
\text { Revisi }\end{array}$ & 10 & 46 & 4,6 & Sangat Baik \\
\hline 2. & $\begin{array}{l}\text { Sesudah } \\
\text { Revisi }\end{array}$ & 10 & 49 & 4,9 & Sangat Baik \\
\hline
\end{tabular}

Berdasarkan tabel 2, dapat disimpulkan bahwa materi dalam produk pengembangan dalam penelitian ini sebelum revisi mendapatkan skor rata-rata 4,6 masuk dalam kategori "Sangat Baik" atau layak digunakan dengan revisi saran dari ahli materi, selanjutnya setelah memperoleh validasi ahli materi, peneliti merevisi produk berdasarkan saran dari ahli materi. Lalu tahap validasi materi sesudah revisi mendapatkan skor rata-rata 4,9 masuk kedalam kategori "Sangat Baik" sehingga produk ini layak untuk di uji coba dilapangan.

Hasil penilaian produk media pembelajaran tas pintar dari ahli materi dalam lembar angket, saran dari ahli materi sebelum digunakan perlu ada beberapa perbaikan. Perbaikan yang disarankan ahli materi adalah sebagai berikut: Tambahkan kotak hasil pada media, tanda operasi penjumlahan tidak permanen, dibuat sesuai kebutuhan, buat 
Kukuh, Rian, Bagus. Empat Kata Judul Dari Depan...

lembar kerja siswa yang representative, buat manual book yang mencakup materi dan cara penggunaan. Setelah memperoleh saran dari ahli materi, peneliti melakukan perbaikan atau merevisi sesuai dengan saran tersebut yaitu membuat kotak hasil pada media, lalu membuat kartu simbol penjumlahan agar tidak permanen, membuat lembar kerja siswa dan membuat manual book yang didalamnya mencakup materi dan cara penggunaan media pembelajaran tas pintar. Media sebelum direvisi dapat dilihat pada gambar 3 dan media sesudah revisi dapat dilihat pada gambar 4.

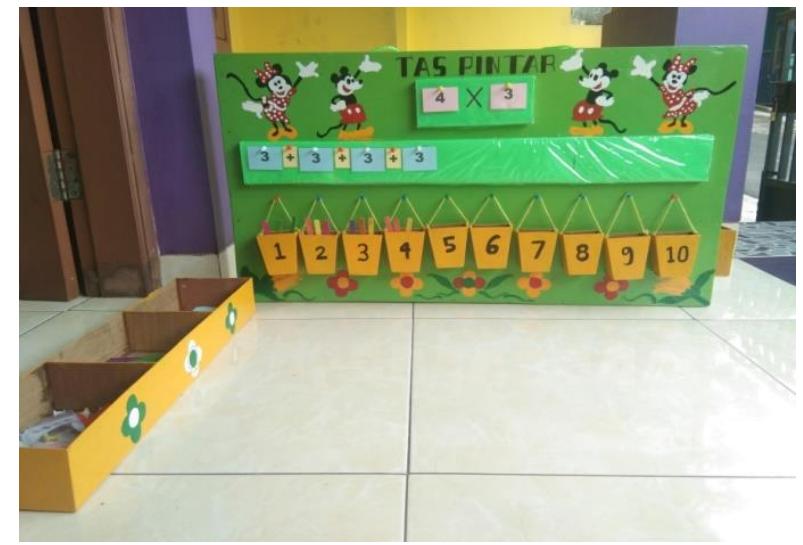

Gambar 4. Media Sesudah di Revisi

\section{Penilaian Produk dan Revisi Produk dari Guru}

Penilaian media pembelajaran ini dilakukan oleh Ibu Ai Titik Sri Pujawati, S.Pd, selaku guru kelas II SDN 1 Papayan. Penilaian yang dilakukan ditinjau dari aspek materi dan media. Pedoman penilaian dan konversi nilai disajikan lengkap pada lampiran 16. Hasil penilaian media pembelajaran tas pintar dapat dilihat pada tabel 5.

Tabel 5. Hasil Penilaian oleh Guru

\begin{tabular}{|c|c|c|c|c|c|}
\hline No & Nama & Butir & $\begin{array}{c}\text { Skor } \\
\text { Perolehan }\end{array}$ & $\begin{array}{c}\text { Rata- } \\
\text { rata } \\
\text { Skor }\end{array}$ & Kategori \\
\hline 1. & $\begin{array}{c}\text { Ai Titik Sri } \\
\text { Pujawati,S.Pd }\end{array}$ & 20 & 100 & 5 & $\begin{array}{c}\text { Sangat } \\
\text { Baik }\end{array}$ \\
\hline
\end{tabular}

Berdasarkan tabel 13, dapat disimpulkan bahwa media dan materi dalam penelitian ini masuk dalam kategori "Sangat Baik". Hal ini menunjukan bahwa media tas pintar ini sangat baik dan layak untuk di uji coba di lapangan. Hasil penilaian produk media pembelajaran tas pintar dari guru dalam lembar angket, disampaikan bahwa media pembelajaran tas pintar ini secara keseluruhan sudah sangat baik, bagus dan sangat kreatif 
Kukuh, Rian, Bagus. Empat Kata Judul Dari Depan...

serta sudah tidak ada masukan lagi dari guru karena materi dan media sudah lengkap sehingga dapat menjadi contoh untuk guru-guru dalam pembuatan media pembelajaran.

\section{Penilaian Produk dari Siswa dalam Uji Coba Terbatas.}

Setelah mendapatkan hasil validasi dari ahli materi, ahli media dan guru, produk diuji coba terbatas terlebih dahulu. Penilaian media pembelajaran tas pintar dalam uji coba terbatas dilakukan oleh 3 orang siswa kelas III SDN 1 Papayan. Penilaian pembelajaran tas pintar oleh 3 orang siswa dapat dilihat pada tabel 6 .

Tabel 6.Hasil Penilaian oleh 3 Siswa dalam Uji Coba Terbatas.

\begin{tabular}{|l|l|c|c|c|c|}
\hline No & Nama & Butir & $\begin{array}{c}\text { Skor } \\
\text { Perole } \\
\text { han }\end{array}$ & $\begin{array}{c}\text { Rata- } \\
\text { rata } \\
\text { Skor }\end{array}$ & Kategori \\
\hline 1. & Nazwita & 8 & 40 & 5 & Sangat Baik \\
\hline 2. & Rama & 8 & 40 & 5 & Sangat Baik \\
\hline 3. & Tasya & 8 & 40 & 5 & Sangat Baik \\
\hline \multicolumn{3}{|c|}{ RATA-RATA } & 120 & 5 & Sangat Baik \\
\hline
\end{tabular}

Berdasarkan tabel penilaian dari uji coba terbatas oleh 3 orang siswa diperoleh nilai rata-rata keseluruhan sebesar 5 yang masuk kedalam kategori "Sangat Baik" yang menunjukan bahwa media pembelajaran tas pintar layak untuk diuji coba lapangan.

\section{Penilaian Produk dari Siswa dalam Uji Coba Lapangan}

Setelah mendapatkan hasil validasi dari ahli materi, ahli media, guru dan 3 siswa dalam uji coba terbatas, pada tahap akhir produk diuji coba lapangan. Penilaian media pembelajaran tas pintar dalam uji coba lapangan dilakukan oleh 25 orang siswa kelas II SDN 1 Papayan. Hasil penilaian media pembelajaran tas pintar pada uji coba lapangan dapat dilihat pada tabel 7. 
Kukuh, Rian, Bagus. Empat Kata Judul Dari Depan...

Tabel 7.

Hasil Penilaian Oleh 25 Siswa Dalam Uji Coba Lapangan

\begin{tabular}{|c|c|c|c|c|}
\hline No & Nama & Butir & $\begin{array}{c}\text { Skor } \\
\text { Perolehan }\end{array}$ & $\begin{array}{c}\text { Rata-Rata } \\
\text { Skor }\end{array}$ \\
\hline 1. & Ageng Ichtiar Wijoyo & 8 & 39 & 4,875 \\
\hline 2. & Alpin Hendriansyah & 8 & 39 & 4,875 \\
\hline 3. & Chika Aprilia & 8 & 39 & 4,875 \\
\hline 4. & Dea Purbaningrum & 8 & 38 & 4,75 \\
\hline 5. & Dewi Aprilia & 8 & 38 & 4,75 \\
\hline 6. & Fahmi Bahrul Ulum & 8 & 40 & 5 \\
\hline 7. & Gisa Anggraeni & 8 & 40 & 5 \\
\hline 8. & Hafifah & 8 & 40 & 5 \\
\hline 9. & Melfa Nur Hidayah & 8 & 37 & 4,625 \\
\hline 10. & Miftah Nurfauzi & 8 & 40 & 5 \\
\hline 11. & Mochamad Azhka Fabrizio & 8 & 40 & 5 \\
\hline 12. & Muhamad Fadlan Herwandi & 8 & 36 & 4,5 \\
\hline 13. & Muhamad Rahmadani & 8 & 38 & 4,75 \\
\hline 14. & Najhan Abdul Manan & 8 & 39 & 4,875 \\
\hline 15. & Nisa Oktaviani & 8 & 40 & 5 \\
\hline 16. & Pazril Maulana & 8 & 37 & 4,625 \\
\hline 17. & Pitri Apriani & 8 & 39 & 4,875 \\
\hline 18. & Resa Dwi Aprilia & 8 & 40 & 5 \\
\hline 19. & Revan febriano & 8 & 37 & 4,625 \\
\hline 20. & Rifky Setia Nugraha & 8 & 39 & 4,875 \\
\hline 21. & Risna Riani & 8 & 37 & 4,625 \\
\hline 22. & Salfa Fauziah & 8 & 40 & 5 \\
\hline 23. & Sri Novitasari & 8 & 35 & 4,375 \\
\hline 24. & Teguh Maulana & 8 & 39 & 4,875 \\
\hline 25. & Yulia Anggraini & 8 & 40 & 5 \\
\hline \multicolumn{3}{|c|}{ Rata-Rata } & 966 & 4,83 \\
\hline \multicolumn{3}{|c|}{ Kategori } & \multicolumn{2}{|c|}{ Sangat Baik } \\
\hline
\end{tabular}

Berdasarkan tabel penilaian dari uji coba lapangan oleh 25 siswa diperoleh nilai rata-rata keseluruhan sebesar 4,83 yang masuk kedalam kategori "Sangat Baik" yang menunjukan bahwa media pembelajaran tas pintar layak digunakan sebagai media pembelajaran untuk materi konsep dasar perkalian.

\section{Hasil Nilai Tes Awal dan Tes Akhir pada Uji Coba Lapangan}

Pada tanggal 29 Februari 2020 dilakukan tes awal terlebih dahulu selama 35 menit, soal diberikan kepada 25 orang siswa kelas II SDN 1 Papayan. Siswa mengisi soal- 
Kukuh, Rian, Bagus. Empat Kata Judul Dari Depan...

soal sebanyak 10 nomor yang berupa soal essay. Hasil nilai tes awal pada uji coba lapangan dapat dilihat ditabel 8.

Tabel 8.

Hasil Nilai Tes Awal Uji Coba Lapangan

\begin{tabular}{|l|l|c|}
\hline No & \multicolumn{1}{|c|}{ Nama } & Nilai \\
\hline 1. & Ageng Ichtiar Wijoyo & 80 \\
\hline 2. & Alpin Hendriansyah & 70 \\
\hline 3. & Chika Aprilia & 90 \\
\hline 4. & Dea Purbaningrum & 70 \\
\hline 5. & Dewi Aprilia & 60 \\
\hline 6. & Fahmi Bahrul Ulum & 90 \\
\hline 7. & Gisa Anggraeni & 70 \\
\hline 8. & Hafifah & 90 \\
\hline 9. & Melfa Nur Hidayah & 80 \\
\hline 10. & Miftah Nurfauzi & 90 \\
\hline 11. & Mochamad Azhka Fabrizio & 70 \\
\hline 12. & Muhamad Fadlan Herwandi & 60 \\
\hline 13. & Muhamad Rahmadani & 80 \\
\hline 14. & Najhan Abdul Manan & 70 \\
\hline 15. & Nisa Oktaviani & 80 \\
\hline 16. & Pazril Maulana & 50 \\
\hline 17. & Pitri Apriani & 60 \\
\hline 18. & Resa Dwi Aprilia & 90 \\
\hline 19. & Revan febriano & 50 \\
\hline 20. & Rifky Setia Nugraha & 80 \\
\hline 21. & Risna Riani & 50 \\
\hline 22. & Salfa Fauziah & 80 \\
\hline 23. & Sri Novitasari & 70 \\
\hline 24. & Teguh Maulana & 70 \\
\hline 25. & Yulia Anggraini & 80 \\
\hline & & 7,320 \\
\hline & & \\
\hline
\end{tabular}

Berdasarkan tabel diatas hasil tes awal uji coba lapangan dapat dilihat bahwa masih ada siswa yang nilainya rendah, jadi pada tes awal masih banyak siswa yang kurang memahami materi konsep dasar perkalian. Pada tanggal 2 maret 2020 dilakukan pembelajaran dengan materi konsep dasar perkalian selama $4 \times 35$ menit. Pertama-tama peneliti melakukan pendahuluan, setelah itu melakukan apersepsi kemudian peneliti menyampaikan tujuan pembelajaran. Untuk kegiatan ini peneliti bertanya kepada siswa tentang konsep perkalian, setelah itu peneliti membagikan buku cara penggunaan media pembelajaran tas pintar lalu dibaca bersama-sama, peneliti memberikan contoh soal dan 
Kukuh, Rian, Bagus. Empat Kata Judul Dari Depan...

menyelesaikan nya dengan menggunakan media pembelajaran tas pintar, setelah itu siswa membuat 5 kelompok lalu mengerjakan lembar kerja siswa, kemudian setiap kelompok maju kedepan dan setiap anggota kelompok masing-masing menyelesaikan soal dengan menggunakan media pembelajaran tas pintar. Setelah itu siswa kembali ke tempat masing-masing dan peneliti melakukan tes akhir dengan membagikan soal tes akhir kepada 25 siswa, tes akhir dilakukan selama 35 menit. Siswa mengisi soal-soal sebanyak 10 nomor yang berupa soal essay sesuai dengan soal yang digunakan pada saat tes awal. Hasil nilai tes akhir pada uji coba lapangan dapat dilihat ditabel 9.

Tabel 9.

Hasil Nilai Tes Akhir Uji Coba Lapangan

\begin{tabular}{|l|l|c|}
\hline No & \multicolumn{1}{|c|}{ Nama } & Nilai \\
\hline 1. & Ageng Ichtiar Wijoyo & 100 \\
\hline 2. & Alpin Hendriansyah & 100 \\
\hline 3. & Chika Aprilia & 100 \\
\hline 4. & Dea Purbaningrum & 80 \\
\hline 5. & Dewi Aprilia & 80 \\
\hline 6. & Fahmi Bahrul Ulum & 100 \\
\hline 7. & Gisa Anggraeni & 100 \\
\hline 8. & Hafifah & 100 \\
\hline 9. & Melfa Nur Hidayah & 100 \\
\hline 10. & Miftah Nurfauzi & 100 \\
\hline 11. & Mochamad Azhka Fabrizio & 100 \\
\hline 12. & Muhamad Fadlan Herwandi & 80 \\
\hline 13. & Muhamad Rahmadani & 100 \\
\hline 14. & Najhan Abdul Manan & 90 \\
\hline 15. & Nisa Oktaviani & 100 \\
\hline 16. & Pazril Maulana & 70 \\
\hline 17. & Pitri Apriani & 80 \\
\hline 18. & Resa Dwi Aprilia & 100 \\
\hline 19. & Revan febriano & 60 \\
\hline 20. & Rifky Setia Nugraha & 100 \\
\hline 21. & Risna Riani & 80 \\
\hline 22. & Salfa Fauziah & 90 \\
\hline 23. & Sri Novitasari & 80 \\
\hline 24. & Teguh Maulana & 90 \\
\hline 25. & Yulia Anggraini & 100 \\
\hline & & 9,120 \\
\hline
\end{tabular}

Berdasarkan tabel diatas hasil tes akhir uji coba lapangan dapat dilihat bahwa nilai yang diperoleh siswa sudah mengalami kenaikan dibanding hasil tes awal, jadi pada tes 
Kukuh, Rian, Bagus. Empat Kata Judul Dari Depan...

akhir setelah menggunakan media tas pintar siswa dapat memahami materi konsep dasar perkalian.

\section{PEMBAHASAN}

\section{Hasil Pengembangan Media Tas Pintar}

Hasil produk media tas pintar dikembangkam dengan dua aspek agar menjadi media yang layak digunakan dalam proses belajar mengajar diantaranya.

\section{Aspek Materi}

Aspek materi yang dikembangkan dalam tas pintar ini diambil dari buku guru dan buku siswa kurikulum 2013 edisi revisi pada tahun 2017. Buku ini diterbitkan oleh Kementrian Pendidikan dan Kebudayaan (Kemendikbud) pada cetakan ke-4. Materi dikembangkan berdasarkan hasil analisis terhadap kompetensi inti, kompetensi dasar dan kemudian dikembangkan menjadi bebebarapa indikator. Indikator yang dikembangkan mengacu pada Kompetensi inti. Analisis dari indikator tersebut dijadikan dasar dalam pemilihan materi yang disesuaikan dengan media tas pintar. Isi materi dan media juga telah disesuaikan dengan tujuan pembelajaran. Hal ini bertujuan agar materi dan kegiatan pembelajaran diarahkan untuk mencapai tujuan pembelajaran (Sukmadinata, 2010).

\section{Aspek Media}

Bahan yang digunakan dalam pembuatan media menggunakan triplek tipis dan tebal, cat warna karton warna 1 buah, kertas hvs warna merah dan biru, tuspin, spidol permanent, steropoam, stik es krim, lem kayu, kuas , penggaris, palu, gunting, paku. bentuk media tas pintar persegi. Yang dilengkapi dengan 10 tas kecil yang terbuat dari triplek tipis, lalu dilengkapi kartu angka merah dan biru. Pemilihan jenis dan ukuran ini bersesuaian dengan pendapat Indrianto (2012) supaya media tidak monoton sertamemberikan kesan yang lebih dinamis dan variatif sehingga tidak membosankan ketika digunakan dalam pembelajaran.Media tas pintar ini juga memperhatikan segi karakteristik siswa di sekolah dasar. Karakteristik siswa sekolah dasar yang masih berbifikir secara operasional konkret. Untuk itu bagi anak sekolah dasar perlu disajikan objek fisik berupa gambar untuk memudahkan siswa dalam mempelajari sesuatu (Jarvis, 2011). Warna gambar dan media ini dibuat semenarik mungkin sehingga siswa mampu untuk memahami materi yang disampaikan. Tas pintar ini merupakan media 
Kukuh, Rian, Bagus. Empat Kata Judul Dari Depan...

yang bisa digunakan dalam pembelajaran kelompok maupun individual. Sehingga siswa bisa belajar bersama teman kelompoknya atau belajar mandiri dengan media tersebut (Khoiriyah \& Sari, 2018).

\section{SIMPULAN}

Berdasarkan hasil penelitian maka dapat ditarik kesimpulan bahwa pengembangan media pembelajaran tas pintar ada 3 tahap yaitu: Define, adalah merumuskan masalah yang menjadi latar belakang atau landasan penelitian pengembangan ini, Desgin, adalah membuat rancangan awal produk yang akan dikembangkan, seperti penyusunan data dan materi, serta penyusunan instrumen untuk penilaian, Develop, adalah tahap melakukan penilaian dan evaluasi oleh ahli media, ahli materi, guru, dan siswa serta menganalisis hasil penialaian kemudian melakukan perbaikan/revisi produk untuk memperoleh produk akhir. Hasil penilaian oleh ahli media, penilaian media pembelajaran tas pintar dari segi media memperoleh skor sebesar 5 masuk dalam kategori sangat baik. Ahli materi menilai media pembelajaran tas pintar dari aspek materi memperoleh skor sebesar 4,9 masuk dalam kategori sangat baik. Penilaian oleh guru media pembelajaran tas pintar dari aspek materi dan media memperoleh skor sebesar 5 masuk dalam kategori sangat baik. Penilaian oleh 3 siswa pada uji coba terbatas memperoleh skor rata-rata 5 masuk kedalam kategori sangat baik. Kemudian penilaian oleh 25 siswa pada uji coba lapangan memeperoleh skor rata-rata 4,83 masuk kedalam kategori sangat baik. Hasil nilai pada tes awal sebelum menggunakan media pembelajaran tas pintar memperoleh skor rata-rata 7,320 dan pada tes akhir setelah pembelajaran menggunakan media tas pintar mengalami kenaikan skor rata-rata yang diperoleh sebesar 9,120. Kesimpulan dari penilaian media tersebut bahwa media pembelajaran tas pintar untuk anak tingkat sekolah dasar dinyatakan layak dan sangat baik digunakan untuk proses pembelajaran pada materi konsep dasar perkalian dan hasil tes awal dan tes akhir menunjukan bahwa media pembelajaran tas pintar efektif digunakan untuk anak tingkat sekolah dasar kelas II.

\section{DAFTAR RUJUKAN}

Arsyad, Azhar. 2015. Media Pembelajaran. Jakarta: Raja Grafindo Persada

Awalia, dkk. 2019. Pengembangan Media Pembelajaran Animasi Powtoon pada Mata Pelajaran Matematika. Jurnal Kreano, Vol. 10 No. 1 
Kukuh, Rian, Bagus. Empat Kata Judul Dari Depan...

Badru, dkk. 2007. Media Pembelajaran. Bandung: UPI PRESS

Fatmatur, dkk. 2017. Desain pembeljaran inovatif dari teori ke praktik. Jakarta: Rajawali Pers.

Febriyanto, Budi. 2018. Peningkatan pemahaman konsep matematis melalui penggunaan media kantong bergambar pada materi konsep dasar perkalian dikelas II Sekolah Dasar. Jurnal Cakrawala Pendas, Vol. 4 No. 2

Herman, dkk. 2007. Pendidikan Matematika 1. Bandung: UPI PRESS

Indrianto, nino. 2012. Pengembangan Bahan Ajar Mata PelajaranPendidikan Agama Islam Berbasis Multikulturalbagi Siswa Kelas XIISMAN2 Kediri. Tesis: Pascasarjana Universitas Islam Negeri Maulana Malik Ibrahim Malang.

Khoiriyah, Evi Sari, \& Eka Yulian. 2018. Pengembangan Media Pembelajaran Pop-Up Book Pada Mata Pelajaran IPA Kelas III SDN 3 Junjung Kecamatan Sumbergempol Kabupaten Tulungagung Tahun Ajaran 2017/2018. Jurnl Bidang Pendidikan Dasar (JBPD), Vol.2 No.2

Komariah, dkk. 2018. Pengembangan media pembelajaran matematika siswa SD berbasis android. Jurnal Kajian Pendidikan Matematika, Vol. 4 No. 1

Kustandi, Cecep, dkk. 2011. Media Pembelajaran Manual dan Digital. Bogor: Ghalia Indonesia

Lestari, Tustika D. 2018. Pengembangan Alat Permainan Edukatif Ular Tangga Perkalian Untuk Siswa Kelas II SD Negeri Ngringin. Jurnal Teknologi Pendidikan, Vol. 7 No. 3

Maolani, Ilam. 2017. Strategi Pembelajaran. Yogyakarta: Leutikaprio

Mucti, dkk. 2018. Pengembangan Media Card 24 pada Siswa SD Pembelajaran Matematika. Jurnal Pendidikan Matematika, Vol. 6 No. 1

Sukiman. 2012. Pengembangan Media Pembeljaran. Yogyakarta: Pedagogia

Sukmadinata, Nana S. 2010. Pengembangan Kurikulum:Teori dan Praktik. Bandung: Remaja Rosdakarya

Sukmadinata, Nana S. 2013. Metode Penelitian Pendidikan. Bandung: Remaja Rosdakarya

Sundayana, Rostina. 2016. Media dan Alat Peraga Dalam Pembelajaran Matematika. Bandung: Alfabeta

Trianto. 2010. Model Pembelajaran Terpadu. Jakarta: Bumi Aksara

Uliyanti, Padmawinata. 2013. Peningkatan aktivitas hasil belajar perkalian dengan media kotakmatika perkalian kelas II SDN 14 Senapit. Jurnal Pendidikan dan Pembelajaran, Vol. 2 No. 4

Widoyoko, Eko P. 2012. Teknik Penyusunan Instrumen Penelitian. Yogyakarta: Pustaka Pelajar

Zubaidah dan Risnawati. 2016. Psikologi Pembelajaran Matematika. Yogyakarta: PT Plosokuning 